Tony Brown / Dennis Atkinson / Janice England

\title{
Regulatory Discourses in Education
}

\section{A Lacanian perspective}

Oxford, Bern, Berlin, Bruxelles, Frankfurt am Main, New York, Wien, 2006. 282 pp.

ISBN 3-03910-527-2 / US-ISBN 0-8204-7532-7 pb.

sFr. 71.- / €* 48.90 / €** 45.70 / £ 32.- / US-\$ 54.95

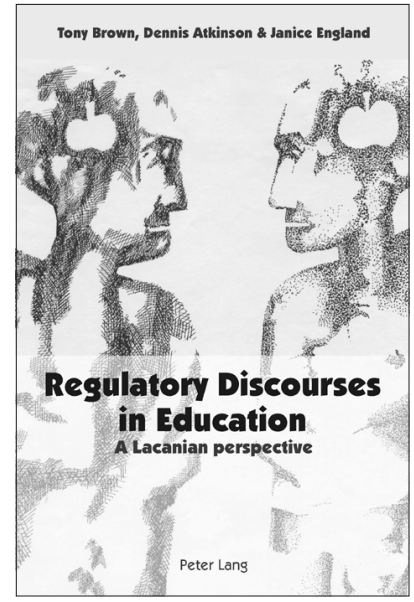

This book employs Lacanian psychoanalysis to develop new ways of understanding educational domains. It analyses events, practices and policies that occur in school classrooms, teacher education and higher-degree studies including educational research. It provides an accessible introduction, description and analysis of those aspects of Lacan's work concerned with language, identity and subjectivity directly relevant to the field of education.

Regulative discourses and practices in education are a central concern and the authors demonstrate how Lacanian theory empowers our understanding of how such discourses are instrumental in forming teacher and researcher identities. The book also shows how regulatory practices and discourses are relevant to research methodologies that arise in the field of action research in education.

Contents: Psychoanalysis and Education - Constructing the Human Subject - Understanding the Pedagogical Object - How Student Teachers Form their Identities - Marginalised Discourses in the Preparation of New Teachers - The Gaze of the Mirror - How Real is the Imaginary? - The Truth of Initial Training Experience - African Tales (with Krista Bradford and Sharon Cargill) - Narrative and Researcher Identity - Haunting the Delusions of Reflection - Emancipatory Aggression - Inclusion, Exclusion and Marginalisation - The Portrayal of Self to the Other.

The Authors: Tony Brown is Professor of Mathematics Education at the Institute of Education at Manchester Metropolitan University where he heads the research student programme. He has published three previous books: Mathematics Education and Language, Action Research and Postmodernism with co-author Liz Jones, and New Teacher Identity and Regulative Government, written with Olwen McNamara.

Dennis Atkinson is Reader in Education at Goldsmiths University of London and Head of the MPhil/PhD Programme in the Department of Educational Studies. He taught for seventeen years in secondary school and is currently Principal Editor of The International Journal of Art and Design Education and has published regularly in academic journals since 1991. He has published two books, Art in Education: Identity and Practice and (edited with Paul Dash) Social and Critical Practice in Art Education.

Janice England is a senior teacher who has worked in city schools in Manchester and Stockport for many years. Her doctoral thesis documenting her work with children has led to a number of internationally published papers.

Our prices are recommended sales prices and do not include postage and handling. Prices are subject to change without notice. We allow a $5 \%$ discount for library orders.

* includes VAT - only valid for Germany and Austria ** does not include VAT

Peter Lang AG · International Academic Publishers

Moosstrasse 1 P. O. Box 350

CH-2542 Pieterlen / Switzerland

I order

copy:

Tony Brown et al.: Regulatory Discourses in Education ISBN 3-03910-527-2 / US-ISBN 0-8204-7532-7 pb. sFr. 71. - / €* 48.90 / €** 45.70 / £ 32.- / US-\$ 54.95
Tel.: ++41(0)32376 1717 · Fax: ++41(0)32 3761727

e-mail: info@peterlang.com

Website: www.peterlang.com

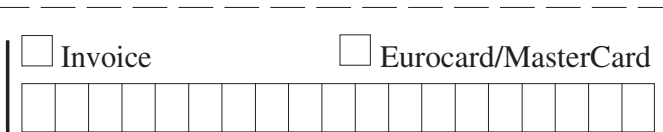

Card No.

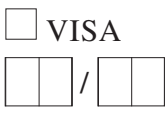

Exp. Date

Signature

\section{Name}

Address
Peter Lang AG

International Academic Publishers

Moosstrasse 1

P. O. Box 350

CH-2542 Pieterlen

Switzerland 